\title{
An approach to derive regional snow lines and glacier mass change from MODIS imagery, western North America
}

\author{
J. M. Shea ${ }^{1,2, *}$, B. Menounos ${ }^{2}$, R. D. Moore ${ }^{1,3}$, and C. Tennant ${ }^{2}$ \\ ${ }^{1}$ Department of Geography, University of British Columbia, Canada \\ ${ }^{2}$ Geography Program, University of Northern British Columbia, Canada \\ ${ }^{3}$ Department of Forest Resource Management, University of British Columbia, Canada \\ * current address: International Centre for Integrated Mountain Development (ICIMOD), in Kathmandu, Nepal
}

Correspondence to: J. M. Shea (jshea@icimod.org)

Received: 31 July 2012 - Published in The Cryosphere Discuss.: 6 September 2012

Revised: 21 February 2013 - Accepted: 17 March 2013 - Published: 18 April 2013

\begin{abstract}
We describe a method to calculate regional snow line elevations and annual equilibrium line altitudes (ELAs) from daily MODIS imagery (MOD02QKM) on large glaciers and icefields in western North America. An automated cluster analysis of the cloud-masked visible and near-infrared bands at $250 \mathrm{~m}$ resolution is used to delineate glacier facies (snow and ice) for ten glacierized regions between 2000-2011. For each region and season, the maximum observed value of the 20th percentile of snowcovered pixels $\left(Z_{S(20)}\right)$ is used to define a regional ELA proxy $\left(E_{L} A_{\text {est }}\right)$. Our results indicate significant increases in the regional ELA proxy at two continental sites (Peyto Glacier and Gulkana Glacier) over the period of observation, though no statistically significant trends are identified at other sites. To evaluate the utility of regional ELA proxies derived from MOD02QKM imagery, we compare standard geodetic estimates of glacier mass change with estimates derived from historical mass balance gradients and observations of $Z_{S(20)}$ at three large icefields. Our approach yields estimates of mass change that more negative than traditional geodetic approaches, though MODIS-derived estimates are within the margins of error at all three sites. Both estimates of glacier mass change corroborate the continued mass loss of glaciers in western North America. Between 2000 and 2009, the geodetic change approach yields mean annual rates of surface elevation change for the Columbia, Lillooet, and Sittakanay icefields of $-0.29 \pm 0.05,-0.26 \pm 0.05$, and $-0.63 \pm 0.17 \mathrm{~m} \mathrm{a}^{-1}$, respectively. This study provides a new technique for glacier facies detection at daily timescales, and contributes to the development of regional estimates of glacier mass change, both of which are critical for studies of glacier contributions to streamflow and global sea level rise.
\end{abstract}

\section{Introduction}

In the next century, wastage of mountain glaciers and icecaps in response to anthropogenic climate change is expected to increase mean global sea levels by 0.051-0.124 m (Cazenave and Nerem, 2004; Raper and Braithwaite, 2006; Radic and Hock, 2011). In western North America, notable area and volume loss of glaciers (Larsen et al., 2007; Schiefer et al., 2007; Berthier et al., 2010; Bolch et al., 2010) and decreased late-summer flows in glacier-fed rivers (Stahl and Moore, 2006; Moore et al., 2009) have already been observed. On annual timescales, surface runoff in glacierized basins is affected by glacier mass change (Moore and Demuth, 2001) which supplements streamflow in years with thin snowpack or dry summers. On longer timescales, reduction in glacier volumes will reduce total streamflow volumes and alter the timing of runoff, yet globally there exist only 37 sites with surface mass balance records longer than $30 \mathrm{yr}$ (Zemp et al., 2011). In western North America, there are only 18 glacier mass balance records longer than $10 \mathrm{yr}$.

Regional assessments of glacier mass change are required to quantify the non-steric fraction of sea level rise, assess changes in glacier contributions to streamflow, and manage water resources in mountain environments. Currently, regional glacier mass change can be estimated from (a) groundbased measurements (Radić and Hock, 2010), (b) anomalies in regional gravity fields (Arendt et al., 2009; Jacob et al., 2012), (c) empirical models (Radić and Hock, 2011), (d) distributed mass balance models (Machguth et al., 2009), and (e) geodetic measurements (Schiefer et al., 2007; Tennant et al., 2012). However, these approaches may be limited in terms of either spatial or temporal resolution, or both. 
Table 1. Area, glacier elevation range, and number of possible MOD02QKM pixels $(N)$ of regional icefields/glacierized regions analysed in this study. Index glacier mass balance sites included in parentheses. Area and elevation range based on GLIMS glacier outlines (Armstrong et al., 2012) and GMTED $200 \mathrm{~m}$ digital elevation model.

\begin{tabular}{lrrr}
\hline Region (index mass balance site) & Area $\left(\mathrm{km}^{2}\right)$ & $Z$ range $(\mathrm{m})$ & $N$ \\
\hline Eastern Alaska Range (Gulkana) & 1298 & $760-2885$ & 18814 \\
Southern Juneau Icefield (Lemon Creek, Taku) & 1451 & $5-2003$ & 22371 \\
Columbia Icefield & 216 & $1721-3624$ & 3436 \\
Wapta/Waputik (Peyto) & 86 & $2078-3203$ & 1363 \\
North Kenai (Wolverine) & 569 & $66-1730$ & 8927 \\
Southern Coast Mountains (Place) & 50 & $1675-2545$ & 805 \\
Rainier (Emmons) & 92 & $1163-4367$ & 1475 \\
South Cascades (S. Cascade) & 19 & $1533-2604$ & 304 \\
Sittakanay Icefield & 399 & $64-2173$ & 6403 \\
Lillooet Icefield & 490 & $911-2958$ & 7845 \\
\hline
\end{tabular}

Geodetic approaches, for example, are limited spatially by the availability of accurate digital elevation data, and temporally by the frequency of such data. Gravity-based methods are unable to resolve mass changes at the scale of individual watersheds or icefields. Distributed and empirical mass balance models rely on the sparse network of mass balance observations for calibration and testing.

An alternative approach to estimate glacier mass change exploits the relation between a glacier's annual net mass balance $\left(B_{\mathrm{n}}\right)$ and its equilibrium line altitude, or ELA (Rabatel et al., 2005). The distinct boundary that separates snowcovered and snow-free zones on a glacier varies both spatially and temporally. During the melt season, this boundary is defined as the transient snow line (Østrem, 1975), and over a large region, the transient snow line approximates the "regional transient snow line". The mean elevation of the transient snow line at the end of the ablation season closely mirrors the ELA (Williams et al., 1991; Klein and Isacks, 1999; Winther et al., 1999; Chinn et al., 2005), which represents the elevation where accumulation is balanced by ablation (Østrem, 1975). One advantage of using ELA to estimate $B_{\mathrm{n}}$ is that it can be regularly measured across a region with suitable space-borne sensors. Others have estimated glacier mass change from ELA observations with air photos (Østrem, 1973) or optical imagery (Rabatel et al., 2005), but the 14day repeat cycle of Landsat, for example, limits its application in mountain environments with pervasive cloud cover.

The MODIS (Moderate Resolution Imaging Spectroradiometer) sensor provides an opportunity to monitor the transient snow line on large mid-latitude glaciers across the globe on a daily basis. The MOD10 snow cover product (Hall et al., 2002), based on normalised difference snow index (NDSI) thresholds, has been used to estimate snow line elevations on large glaciers (Pelto, 2011), validate hydrological models (Parajka and Blöschl, 2008) and to map snow cover in large watersheds (Déry and Brown, 2007). Unfortunately, the $500 \mathrm{~m}$ resolution of the MOD10 product and its poor discrimination between snow and ice facies (Hall and Riggs, 2007) make it less suitable for use on mountain glaciers. The MOD02QKM product contains calibrated and geolocated radiances in the red $(0.620-0.670 \mu \mathrm{m})$ and nearinfrared $(0.841-0.876 \mu \mathrm{m})$ bands with spatial resolutions of $250 \mathrm{~m}$ at nadir. Others have used these bands to calculate subpixel fractional snow cover and monitor snow line evolution (Lopez et al., 2008; Sirguey et al., 2009), and a recent study developed estimates of mass change from MODIS-derived surface albedos (Dumont et al., 2012).

In this study, we employ the $250 \mathrm{~m}$ visible and nearinfrared bands of MODIS to estimate transient snow line elevations and annual ELA $\left(\mathrm{ELA}_{\mathrm{est}}\right)$ for ten glacierized regions in western North America. Relations between regional ELAs and ground-based observations of glacier mass balance at seven field sites are examined, and correlations and trends in regional ELA are identified. We extend our approach to estimate the mass change of three large icefields using historical mass balance gradients, and compare these results to geodetic estimates of mass change. Basin-scale estimates of glacier mass change are useful for diagnosing glacier contributions to streamflow and sea level rise, and the approach developed here complements other estimates of glacier mass change.

\section{Data and methods}

\subsection{Site selection}

Our analyses focus on index glacier mass balance sites near large icefields in western North America, where either ground observations of surface mass balance or geodetic estimates of glacier mass change are available. Between 2000 and 2009, net glacier mass balance is reported for 24 sites in western North America (Zemp et al., 2011). Of these, 14 glaciers are less than $2 \mathrm{~km}^{2}$ in area, and a large majority are clustered in the North Cascades region (Pelto and Riedel, 2001). We use eight glacier mass balance sites 


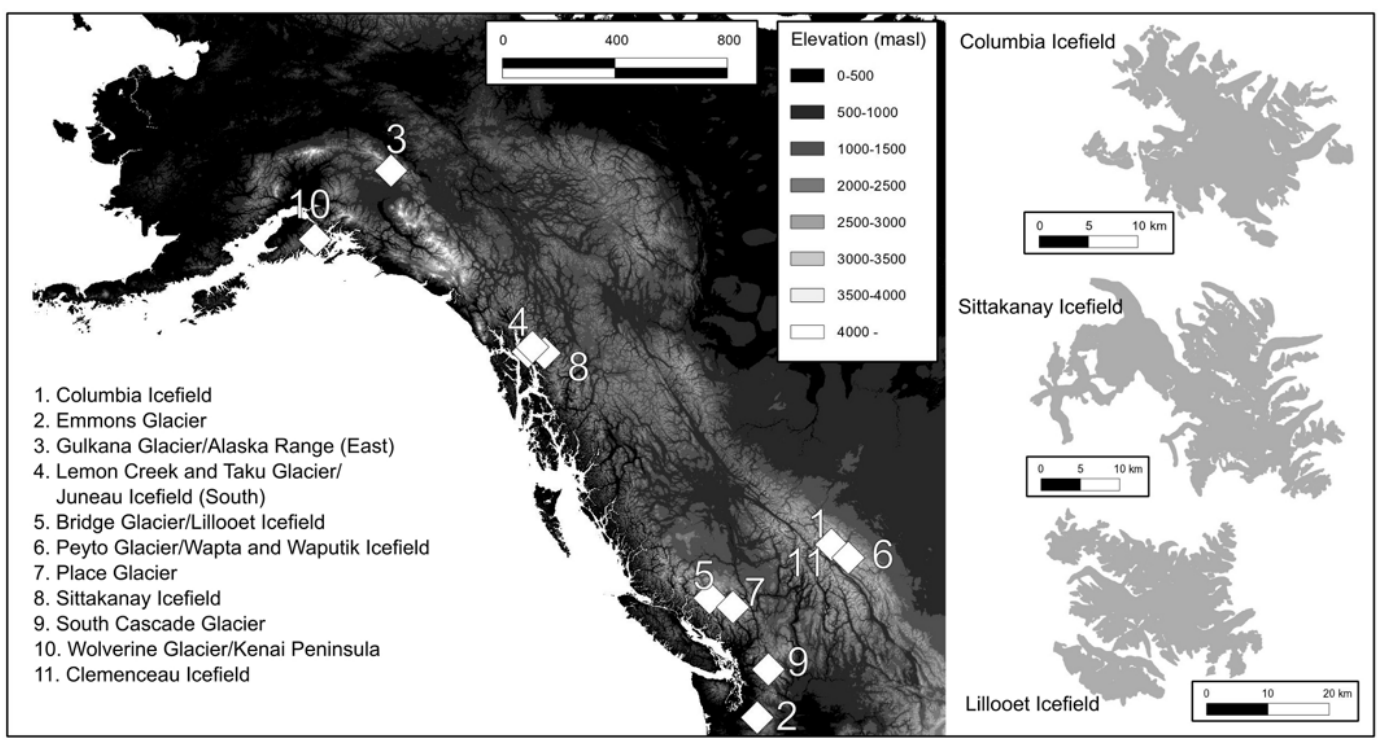

Fig. 1. Study area, with locations of index glaciers and geodetic mass balance sites. Columbia, Lillooet, Sittakanay icefields shown for comparison.

(Fig. 1, Table 1) where the index glacier area exceeds $2 \mathrm{~km}^{2}$, and adjacent terrain contains numerous glaciers which are required to test our approach.

We test our approach on three large icefields (Columbia, Lillooet, and Sittakanay) where both historical mass balance data by elevation band and geodetic estimates of glacier mass change are available. Peyto Glacier is a long-term mass balance monitoring site, located approximately $75 \mathrm{~km}$ southeast of the Columbia Icefield (Fig. 2), and mass balance data are available from 1965-2005 (Mokievsky-Zubok et al., 1985; Dyurgerov, 2002). Bridge Glacier is a tributary of the Lillooet Icefield (Fig. 3), and mass balance data by elevation band are available from 1977-1985 (Mokievsky-Zubok et al., 1985; Demuth and Keller, 1997; Dyurgerov, 2002). Mass balance data for the Andrei Glacier from 1977-1985 were obtained from Mokievsky-Zubok et al. (1985) and Dyurgerov (2002), with additional mass balance data for 1989-1991 extracted from BC Hydro reports (MokievskyZubok, 1990, 1991, 1992). Andrei Glacier lies approximately $100 \mathrm{~km}$ southeast of the Sittakanay Icefield (Fig. 1).

\subsection{MOD02QKM classification}

MOD02QKM and MOD10L2 scenes covering western North America were obtained for the end of the ablation season (15 August-15 October) between 2000 and 2009 (NASA, 2012; Hall et al., 2012). Between two and four scenes were analysed per day, which represents about 1830 scenes over the study period. The actual number of scenes used for each site and season (Table 2) primarily depends on cloud cover. MOD02QKM and MOD10L2 imagery were projected first to $\mathrm{BC} \mathrm{Al}-$ bers using the HDF-EOS to GIS Format Conversion Tool (HEG, http://gcmd.nasa.gov/records/HEG.html, last accessed 10 November 2012). After the MOD10L2 product was resampled to $250 \mathrm{~m}$ resolution using the Geospatial Data Abstraction Library (GDAL), the cloud mask was extracted and applied to the MOD02QKM imagery.

Cloud-masked visible and near-infrared bands were subsequently clipped to glacierized regions using publicly available digital outlines of the glaciers obtained from the Global Land Ice Monitoring from Space (GLIMS) database (Armstrong et al., 2012). At $250 \mathrm{~m}$ resolution, the MOD02QKM product is too coarse to classify snow and ice on small glaciers. For each mass balance site, we thus use a regional sample of glaciers to classify snow and ice facies and calculate $\mathrm{ELA}_{\mathrm{est}}$. At each site and day, an unsupervised k-means cluster analysis of the visible and near-infrared bands was conducted to classify all glacierized and cloud-free pixels as either snow or ice. The kmeans 2 module in Python (Scipy) was used to perform the unsupervised k-means cluster analysis, which minimises the Euclidean Distance between cluster means. Errors due to topographic shading were minimised by analysing scenes that were obtained between $10 \mathrm{a} . \mathrm{m}$. and 3 p.m. local time, though shading on north-facing slopes will still occur. The effects of atmospheric variability (smoke, haze) on the cluster analysis results are unknown. To avoid sampling errors due to excessively cloudy conditions or fresh snowfall events, we analysed scenes with less than $50 \%$ cloud cover and greater than $5 \%$ ice cover, as defined by the MOD10L2 product. 

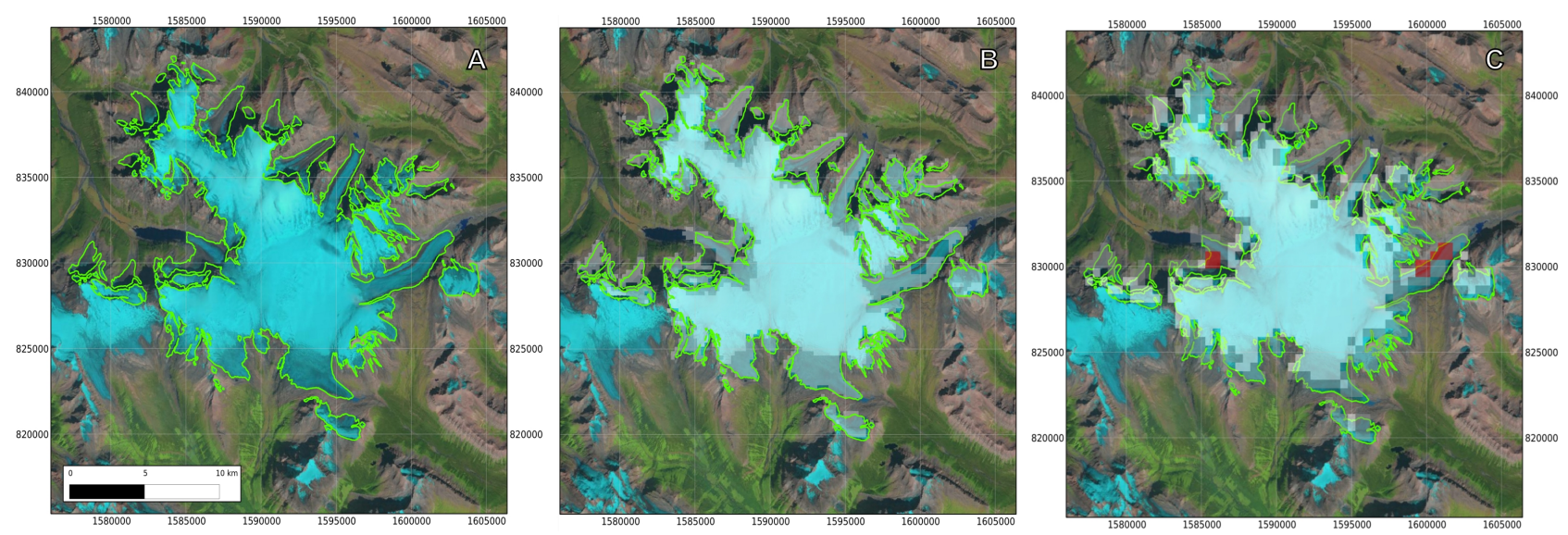

Fig. 2. (A) Landsat 5 scene of Columbia Icefield, 29 August 2009, with (B) corresponding MOD02 snow (white) and ice (grey) clusters, and (C) MOD10 snow cover product. Cloud-obscured pixels in (C) are shown in red. Map coordinates are in metres, and refer to the BC Albers projection.
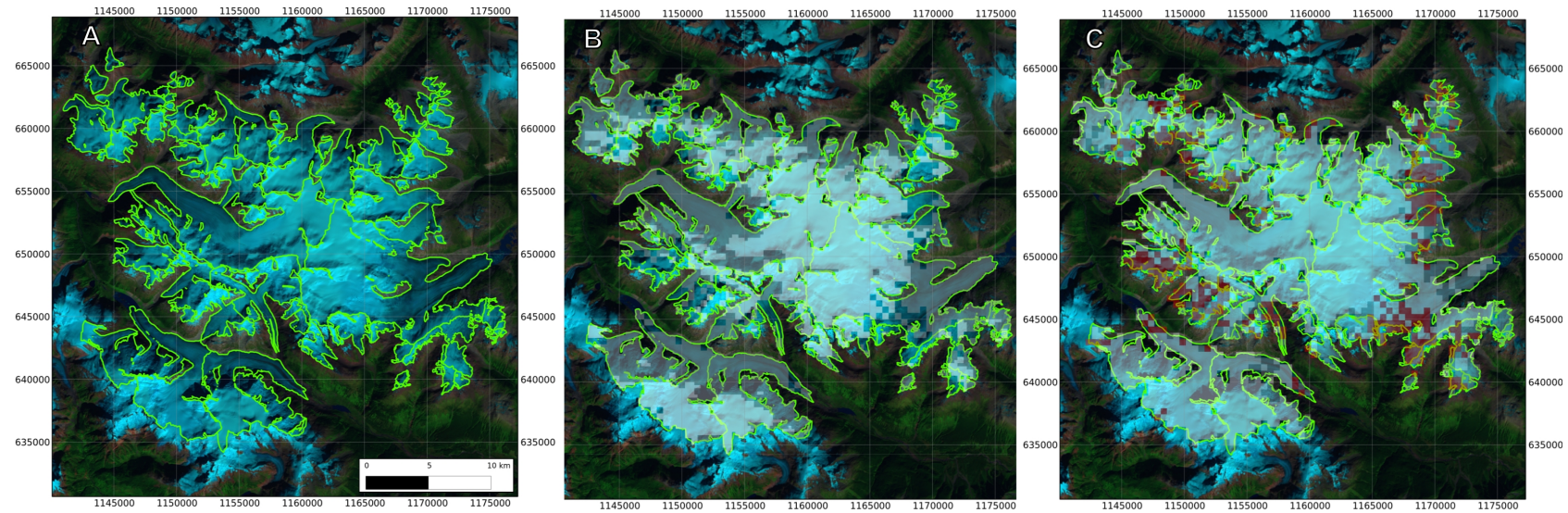

Fig. 3. (A) Landsat 5 scene of Lillooet Icefield, 5 September 2001, with (B) corresponding MOD02 snow (white) and ice (grey) clusters, and (C) MOD10 snow cover product. Cloud-obscured pixels in $(\mathbf{C})$ are shown in red.

\subsection{Estimation of Regional ELA}

Localised enhancements of accumulation (e.g. by wind redistribution) or ablation (e.g. south-facing slopes) can result in large variations in snow line elevation across the surface of a glacier or icefield on any given day. To generate estimates of ELA $A_{\text {est }}$ from MOD02QKM imagery, we resample digital elevation models (DEMs) from the Global Multi-resolution Terrain Elevation Data (GMTED) and the Shuttle Radar Topography Mission (SRTM) digital elevation datasets (Gesch et al., 2002; Farr et al., 2007) to $250 \mathrm{~m}$ resolution. For each classified scene and region, we then calculate the mean, range, and quantiles of elevation for the snow and ice classes, and construct time series of each metric (e.g. Fig. 4).

To quantify ELA $_{\text {est }}$ a locally weighted least squares (lowess) regression, with points weighted by the proportion of cloud-free pixels, is fit for each snow line metric. In this study, we focus specifically on the 10th and 20th percentiles of snow-covered pixel elevations $\left(Z_{S(10)}, Z_{S(20)}\right)$, accumulation area ratios (AAR), and the arithmetic mean of the snow line contour $\left(Z_{\mathrm{SL}}\right)$. For each region, the maximum seasonal values of $Z_{S(10)}, Z_{S(20)}$, and $Z_{S L}$ were compared with observed index glacier net mass balance.

\subsection{Regional Glacier Mass Change}

We extend the approach of Rabatel et al. (2005) to estimate annual net mass balance at $100 \mathrm{~m}$ elevation bands $\left(b_{\mathrm{n}}\right)$ using a piecewise linear spline (Fountain and Vecchia, 1999) with separate mass balance gradients above and below the ELA $\mathrm{est}_{\mathrm{e}}$ :

$b_{n(j)}=\left\{\begin{array}{l}b_{1}\left(b_{0}-Z_{j}\right), Z_{j} \leq b_{0} \\ b_{2}\left(Z_{j}-b_{0}\right), Z_{j}>b_{0},\end{array}\right.$

where $b_{0}$ is ELA est, $b_{1}$ and $b_{2}$ are mass balance gradients $\left(\mathrm{mm}\right.$ w.e. $\mathrm{m}^{-1}$ ) below and above ELA $\mathrm{est}_{\mathrm{es}}$, respectively, and 
Table 2. Number of MOD02QKM scenes that meet criteria for time of acquisition, cloud cover, and snow extent thresholds for each index glacier/icefield region and year.

\begin{tabular}{lrrrrrrrrrrr}
\hline Site & 2000 & 2001 & 2002 & 2003 & 2004 & 2005 & 2006 & 2007 & 2008 & 2009 & Totals \\
\hline Columbia & 18 & 26 & 15 & 17 & 18 & 14 & 41 & 15 & 21 & 21 & 206 \\
Emmons & 34 & 46 & 46 & 18 & 40 & 32 & 55 & 38 & 31 & 38 & 378 \\
Gulkana & 8 & 17 & 12 & 13 & 17 & 13 & 11 & 13 & 3 & 13 & 120 \\
Lemon Creek/Taku & 3 & 6 & 5 & 12 & 21 & 8 & 10 & 11 & 4 & 14 & 94 \\
Lillooet & 27 & 24 & 39 & 11 & 21 & 16 & 44 & 21 & 25 & 28 & 256 \\
Peyto & 17 & 25 & 12 & 17 & 13 & 14 & 40 & 15 & 17 & 24 & 194 \\
Place & 25 & 27 & 33 & 12 & 27 & 17 & 47 & 22 & 25 & 29 & 264 \\
Sittakanay & 1 & 9 & 8 & 14 & 14 & 8 & 8 & 12 & 6 & 12 & 92 \\
S. Cascade & 28 & 32 & 35 & 16 & 31 & 28 & 51 & 25 & 22 & 41 & 309 \\
Wolverine & 19 & 8 & 18 & 19 & 36 & 9 & 15 & 19 & 7 & 17 & 167 \\
\hline
\end{tabular}
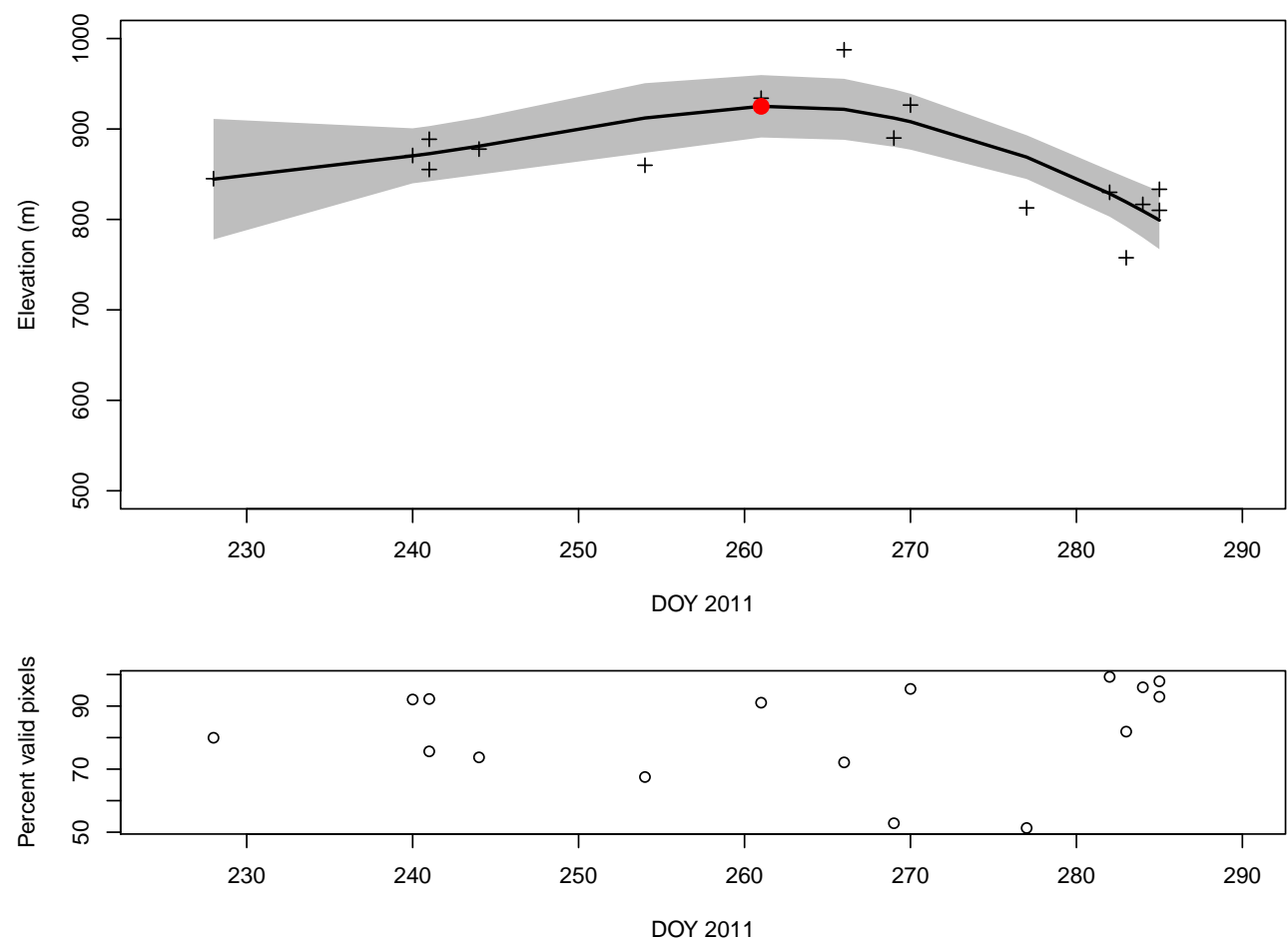

Fig. 4. Top panel: observations (crosses) of $Z_{S(20)}$ by day of year (DOY) for the Wolverine Glacier region, 2011 ablation season. The lowess curve (black) with standard errors (grey) is weighted by the percentage of cloud-free pixels (bottom panel) in each scene. The maximum value on the lowess curve (red) is assumed to represent the annual ELA.

$Z_{j}$ is the midpoint of elevation band $j(\mathrm{~m})$. Values for $b_{1}$ and $b_{2}$ at each icefield were obtained by setting $b_{0}$ as a free parameter, and fitting Eq. (1) to annual net mass balance observations at Peyto, Bridge, and Andrei glaciers (Fig. 5). Average fitted values for $b_{1}$ and $b_{2}$ range from 5.17 to $7.25 \mathrm{~mm} \mathrm{~m}^{-1}$ and 2.15 to $4.07 \mathrm{~mm} \mathrm{~m}^{-1}$, respectively (Table 3).

Hypsometric data derived from the GLIMS glacier boundaries and the SRTM DEMs were then used with Eq. (1) to estimate annual $B_{\mathrm{n}}$. Errors in ELA $\mathrm{E}_{\mathrm{est}}$ estimates of volume change were computed from the standard error in the weighted lowess curves and an assumed error in mass balance gradients of $10 \%$. Our choice of an assumed error of $10 \%$ for mass balance gradients is arbitrary, and attempts to reflect the possible errors in misspecified mass balance gradients. Uncertainty in $Z_{S(20)}$ is primarily related to the frequency of cloud-free scenes.

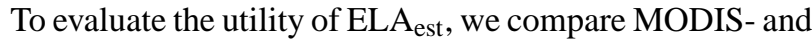
geodetic-derived estimates of mass change at the Columbia, Lillooet and Sittakanay icefields. Using SPOT and SRTM DEMs (Table 4), icefield geodetic balances were computed following the methods of Schiefer et al. (2007) and 

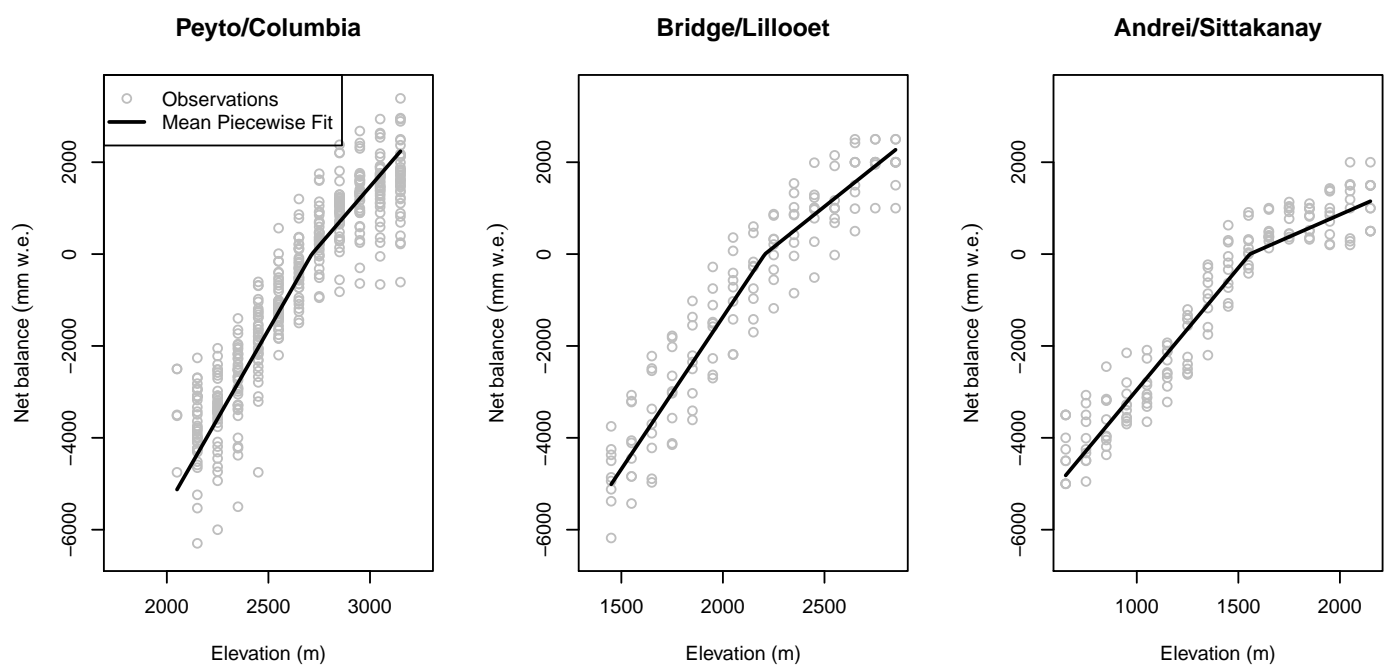

Fig. 5. Observed net mass balance by elevation band for Peyto (Columbia), Bridge (Lillooet), and Andrei (Sittakanay) glaciers and icefields. Solid black lines denote mean fitted mass balance gradients.

Table 3. Median elevations $\left(Z_{\text {med }}\right.$, in $\mathrm{m}$ a.s.1.) for mass balance sites and glacierized regions, and mean $(\bar{x})$ and standard deviation $(\sigma)$ of fitted mass balance gradients, in $\mathrm{mm}$ w.e. $\mathrm{m}^{-1}$. Standard deviation is also shown as a percentage of the mean in brackets.

\begin{tabular}{lrrrrrr}
\hline Site/Icefield & $\begin{array}{r}\text { Glacier } \\
Z_{\text {med }}(\mathrm{m})\end{array}$ & $\begin{array}{r}\text { Regional } \\
Z_{\text {med }}(\mathrm{m})\end{array}$ & $\bar{x}_{b 1}$ & $\bar{x}_{b 2}$ & $\sigma_{b 1}(\%)$ & $\sigma_{b 2}(\%)$ \\
\hline Andrei/Sittakanay & 1589 & 1388 & 5.48 & 2.09 & $0.74(13.5)$ & $0.77(36.5)$ \\
Bridge/Lillooet & 2272 & 2318 & 6.62 & 3.53 & $1.46(22.0)$ & $0.74(20.9)$ \\
Peyto/Columbia & 2644 & 2689 & 7.48 & 4.01 & $1.27(17.1)$ & $1.87(46.7)$ \\
\hline
\end{tabular}

Tennant et al. (2012). For each icefield, SPOT and SRTM DEMs were reprojected to $\mathrm{BC}$ Albers and resampled to a $90 \mathrm{~m}$ resolution. The resulting DEMs were then differenced and elevation changes on stable areas free of ice and vegetation were analysed. Using the stable areas, we checked for co-registration by plotting elevation change normalised by the tangent of the slope versus aspect (Nuth and Kääb, 2011). If the DEMs are accurately co-registered, there should be no bias in this plot. The Columbia and Lillooet icefield DEMs showed no significant bias. There was a bias between the Sittakanay Icefield DEMs, which was modelled and removed using the methods of Nuth and Kääb (2011). Biased estimates of glacier elevation changes may also arise due to SRTM radar penetration. Where possible, we corrected our SRTM elevation data for radar penetration over glacierized surfaces and resolution following the methods of Gardelle et al. (2012). SRTM X-band data were not available for the Lillooet Icefield scene, so radar penetration corrections were performed only for the Columbia and Sittakanay icefields.
Table 4. Imagery used in geodetic mass change calculations.

\begin{tabular}{lll}
\hline Site & Imagery & Acquisition date \\
\hline Columbia & SRTM & Feb 2000 \\
& SPOT-5 & 20 Aug 2009 \\
& SPOT-5 & 30 Aug 2009 \\
Lillooet & SRTM & Feb 2000 \\
& SPOT-5 & 20 Aug 2009 \\
& SPOT-5 & 29 Aug 2009 \\
Sittakanay & SRTM & Feb 2000 \\
& SPOT-5 & 2 Jul 2008 \\
\hline
\end{tabular}

\section{Results}

\subsection{Glacier surface classification}

Comparisons of the cluster analysis results and contemporaneous Landsat scenes demonstrate that the MOD02QKM product can be used to successfully discriminate between snow and ice facies (Figs. 2, 3, and 6). In contrast to the MOD10 binary snow product, the MOD02QKM cluster analysis technique developed in this study also provides 
Table 5. Comparison of snow line metrics derived from manual delineation of snow and ice classes (Landsat scene) and automated classification from MOD02QKM cluster analysis.

\begin{tabular}{lccccc}
\hline & \multicolumn{2}{c}{ Wapta/Waputik, 20 Aug 2009 } & & \multicolumn{2}{c}{ Lillooet, 4 Oct 2001 } \\
\cline { 2 - 3 } \cline { 6 - 6 } Metric & Manual & Automatic & & Manual & Automatic \\
\hline$Z_{S(10)}(\mathrm{m})$ & 2631 & 2624 & & 2102 & 2132 \\
$Z_{S(20)}(\mathrm{m})$ & 2656 & 2655 & & 2203 & 2245 \\
$A A R$ & 0.47 & 0.34 & & 0.73 & 0.52 \\
$Z_{\text {SL }}(\mathrm{m})$ & 2671 & 2408 & & 2089 & 2050 \\
\hline
\end{tabular}

improved discrimination between snow and ice surfaces over large glaciers and icefields. To evaluate our approach, we compared snow lines manually digitized from highresolution Landsat imagery with the cluster analysis results (Figs. 7 and 8; Table 5).

Snow line metrics $\left(Z_{S(10)}, Z_{S(20)}\right.$, AAR, $\left.Z_{\mathrm{SL}}\right)$ were calculated for both the manual and automated classifications using the $90 \mathrm{~m}$ SRTM DEM (Table 5). Despite some differences in the delineated snow lines, the general snow line patterns and derived snow line metrics are similar. Automated (MOD02QKM) and manually-derived (Landsat) values of $Z_{S(20)}$ for the Wapta/Waputik icefield on 20 August 2009, for example, are 2656 and $2655 \mathrm{~m}$, respectively. For the Lillooet Icefield on 4 October 2001, the $Z_{S(20)}$ metric manually derived from Landsat imagery is $2203 \mathrm{~m}$, while the MOD02QKM cluster analysis gives $Z_{S(20)}=2245$. Differences in $Z_{S(10)}$ are similarly small between the manual and automated classifications, while differences in derived AARs and mean snow line elevations $\left(Z_{\mathrm{SL}}\right)$ are substantial.

\subsection{Regional ELA and glacier mass balance}

Relations between observed glacier mass balance and ELA $A_{\text {est }}$ were examined using the WGMS net mass balance data. The $Z_{S(20)}$ regional ELA proxy is a significant predictor of glacier mass balance at four of eight index glacier mass balance sites in western North America (Fig. 9). Simple linear regressions between regional ELA and observed $B_{\mathrm{n}}$ are significant at $\alpha=0.05$ for Peyto, Gulkana, Wolverine, and South Cascade glaciers. We do not find significant relations between maximum $Z_{S(20)}$ and $B_{\mathrm{n}}$ at Place Glacier, or Emmons Glacier, and $p$ values at Lemon Creek and Taku Glacier are 0.169 and 0.122 , respectively. The failure of this approach at Place and Emmons glaciers may be related to glacier size (Place Glacier is less than $4 \mathrm{~km}^{2}$ ), sample size ( $n=4 \mathrm{yr}$ at Emmons Glacier), and/or the representativeness of these glaciers within their glacierized regions.

Overall, the $Z_{S(20)}$ ELA proxy provides a better estimate of field-based estimates of ELA compared to mean snow line elevations $\left(Z_{\mathrm{SL}}\right.$; Fig. 10). We find significant relations between the $Z_{S(20)}$ estimate of ELA and the ELA based on mass balance measurements at only two sites (Peyto and Taku glaciers). However, the regional ELA $\mathrm{Est}_{\text {is }}$ is not likely to be equivalent to the ELA reported for a single glacier. The observed ELA represents the elevation where $B_{\mathrm{n}}=0$, and this is typically taken from interpolated observations of net

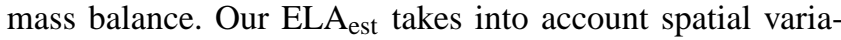
tions in snow cover and snow line elevation, which will vary with slope, aspect, and shading, and will represent the entire icefield or region.

Simple linear trends in the $Z_{S(20)}$ ELA proxy were calculated over the period 2000-2011 (Fig. 11). Annual rates of change in the $Z_{S(20)}$ ELA proxy at Gulkana Glacier and Peyto Glacier, respectively, were $+16.8 \mathrm{~m} \mathrm{a}^{-1}(p=0.04)$, and $+2.9 \mathrm{~m} \mathrm{a}^{-1}(p=0.09)$. No significant trends in regional ELA were found at other index glacier sites. In comparison, geomorphic evidence suggests that the ELA of the Clemenceau Icefield, located approximately $100 \mathrm{~km}$ northwest of Peyto Glacier, has increased between 100 and $200 \mathrm{~m}$ from the Little Ice Age (LIA) to 2001 (Jiskoot et al., 2010). Assuming a LIA maximum at ca. 1850 (Luckman, 2000), this represents an average ELA rise between +0.7 and $+1.3 \mathrm{~m} \mathrm{a}^{-1}$, versus our estimate of $+2.9 \mathrm{~m} \mathrm{a}^{-1}$ over the period 2000-2009 for the Peyto Glacier region.

The correlations of ELA $\mathrm{Est}_{\mathrm{en}}$ anomalies calculated for the 10 regions examined in this study are complex (Table 6). ELA $_{\text {est }}$ anomalies derived for Peyto Glacier region, for example, are significantly correlated $(r=0.75)$ with those obtained for the Columbia Icefield, but regional ELAs at Place Glacier are not significantly correlated with those observed at the Lillooet Icefield, which is located only $75 \mathrm{~km}$ to the northwest (Fig. 1). Regional ELA anomalies observed at the South Cascade site are significantly correlated with a number of locations in the Pacific Northwest, including Peyto Glacier $(r=0.50)$, Emmons Glacier $(r=0.61)$, Lillooet Icefield $(r=0.72)$ and Place Glacier $(r=0.84)$. Weak negative correlations between regional ELAs observed at Alaskan (Wolverine and Gulkana) and southern sites (Emmons, Place, Lillooet) support previously documented north-south reversals in mass balance signals in response to large-scale atmospheric circulation patterns (Bitz and Battisti, 1999; McCabe et al., 2000).

\subsection{Estimates of glacier mass change}

Geodetic estimates of glacier mass change (Table 7) at the three icefields examined in this study range between $-0.62 \pm 0.11$ and $-2.10 \pm 0.57 \mathrm{Gt}$. To put these results in context, total mass changes (in Gt) were converted to $\mathrm{ma}^{-1}$ using the icefield area, the years between image acquisition, and the density of water $\left(1000 \mathrm{~kg} \mathrm{~m}^{3}\right)$. The geodetic mass change rate at the Columbia Icefield $\left(-0.29 \mathrm{~m} \mathrm{a}^{-1}\right)$ is half that observed between 1985 and $1999\left(-0.64 \mathrm{~m} \mathrm{a}^{-1}\right.$, Schiefer et al. (2007), hereafter S07). Previously reported rates of surface elevation change at the Andrei Icefield range between -0.5 (1965-1982) and -1.1 (1985-1999) $\mathrm{ma}^{-1}$ (S07). Our geodetic estimates of mass change at the nearby Sittakanay Icefield between 2000 and $2007\left(-0.63 \mathrm{~m} \mathrm{a}^{-1}\right)$ 

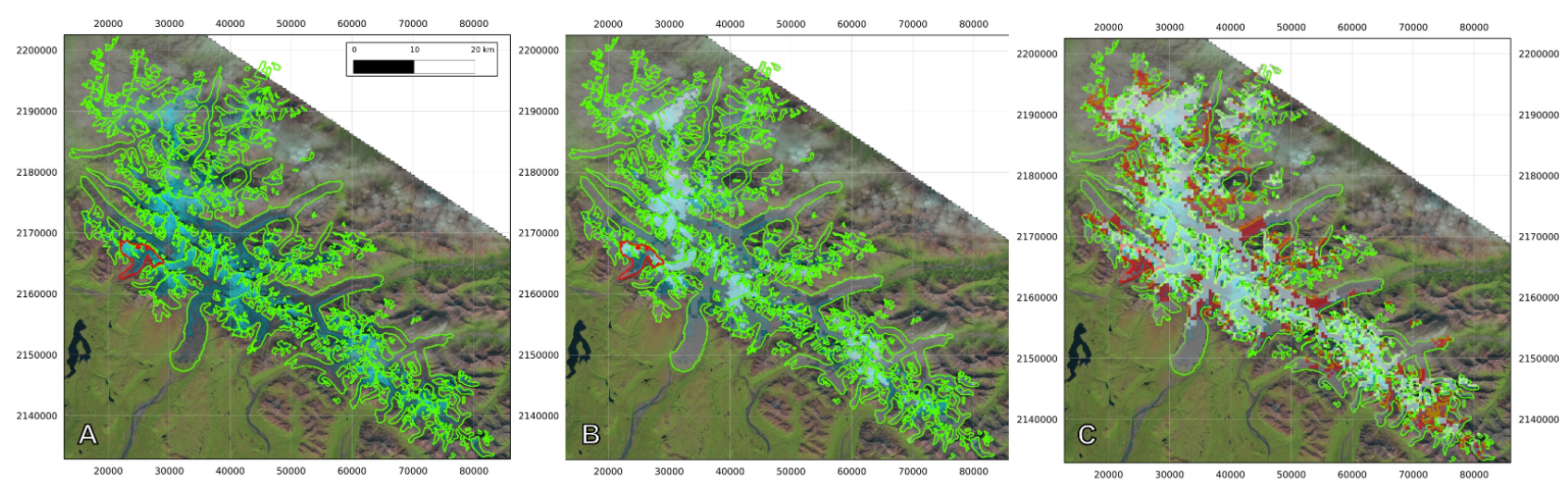

Fig. 6. (A) Landsat 5 scene of the eastern Alaska Ranges, 15 August 2004, with (B) 22 August 2004 MOD02 snow (white) and ice (grey) clusters, and (C) 22 August 2004 MOD10 snow cover product. Cloud-obscured pixels in (C) are shown in red. Gulkana Glacier is highlighted in red.

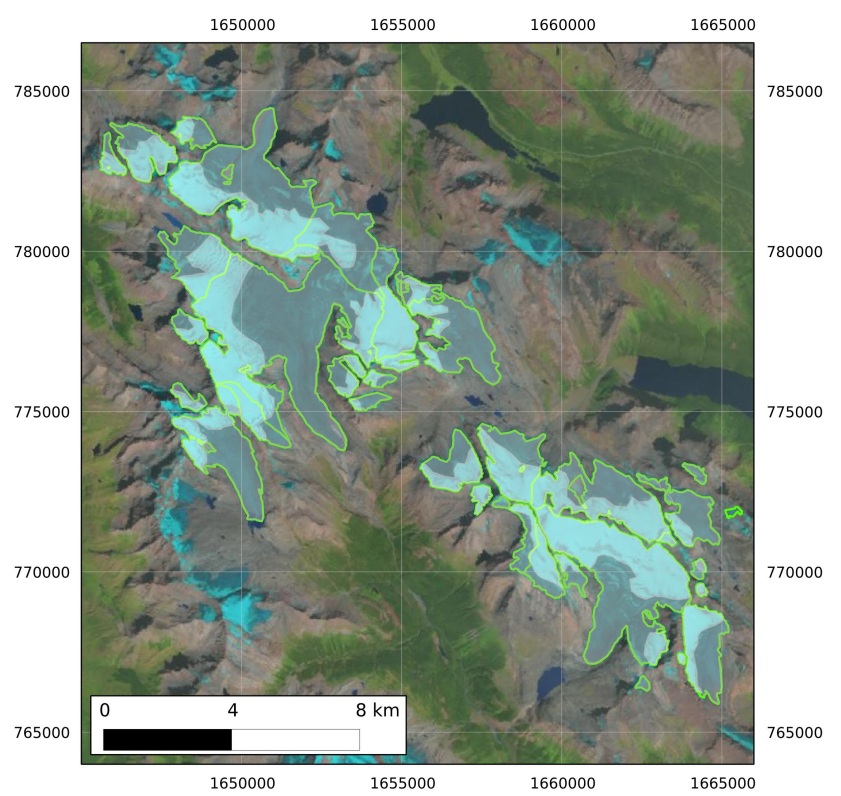

(a) Manual snow/ice classification

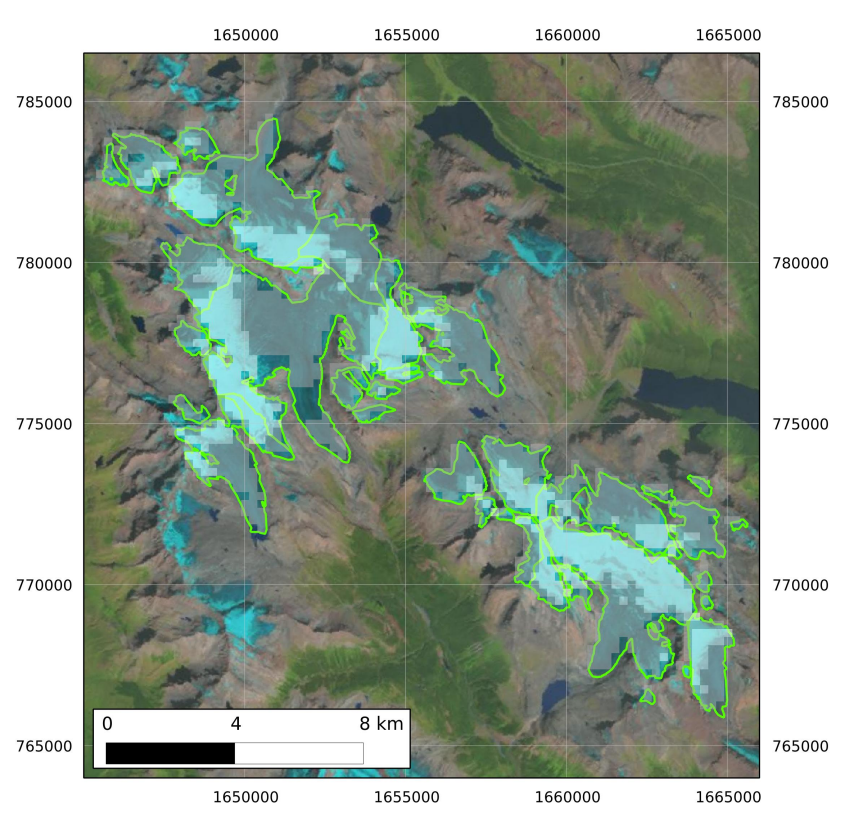

(b) Automated MOD02QKM classification

Fig. 7. Landsat 5 scene of the Wapta/Waputik Icefield and Peyto Glacier, 20 August 2009, with (a) manual classification, and (b) MOD02QKM automated classification of snow (white) and ice (grey).

suggests continued high rates of mass loss in this region. At Lillooet Icefield, the geodetic rate of glacier mass change calculated between 2000 and 2009 is $-0.26 \mathrm{~m} \mathrm{a}^{-1}$, compared to a rate of $-0.6 \mathrm{~m} \mathrm{a}^{-1}$ observed between 1970 and 1988 (S07).

Taking the geodetic approach as the true estimate of

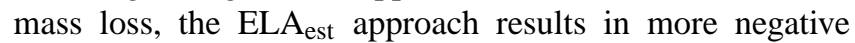
mass changes at all three sites (Table 7). At the Lillooet Icefield, ELA $\mathrm{Est}_{\mathrm{es}}$ mass loss $(-2.24 \pm 0.80 \mathrm{Gt})$ is nearly twice that derived from traditional geodetic approaches $(-1.28 \pm 0.26 \mathrm{Gt})$. At Sittakanay Icefield, the ELA $\mathrm{Est}_{\mathrm{ep}}$ approach produces a mass loss of $-3.00 \pm 0.59 \mathrm{Gt}$, versus a geodetic estimate of $-2.10 \pm 0.57 \mathrm{Gt}$. The ELA $\mathrm{Asst}_{\text {approach }}$ appears to work best at the Columbia Icefield, where the two approaches differ by $0.12 \mathrm{Gt}$ (or $0.06 \mathrm{~m} \mathrm{a}^{-1}$ ) over the $10 \mathrm{yr}$ period of calculation. Possible reasons for these discrepancies are discussed below.

\section{Discussion}

Our approach can be readily applied to construct time series of transient regional snow line elevations and regional equilibrium line altitudes on large glaciers and icefields using moderate resolution optical imagery. Comparisons of snow line metrics manually extracted from $30 \mathrm{~m}$ resolution Landsat imagery and an automated cluster analysis of $250 \mathrm{~m}$ 


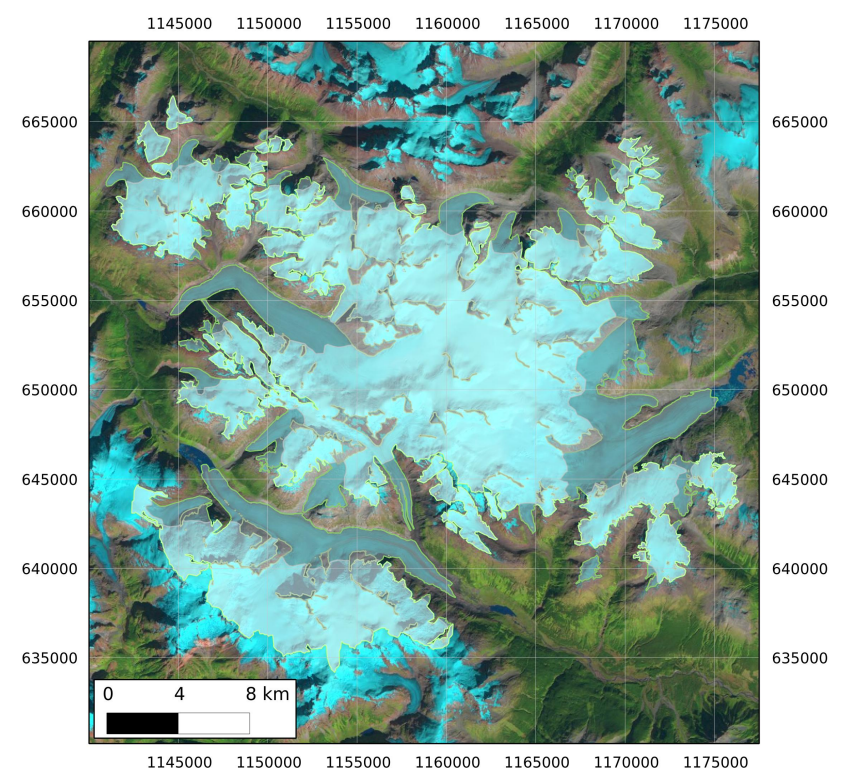

(a) Manual snow/ice classification

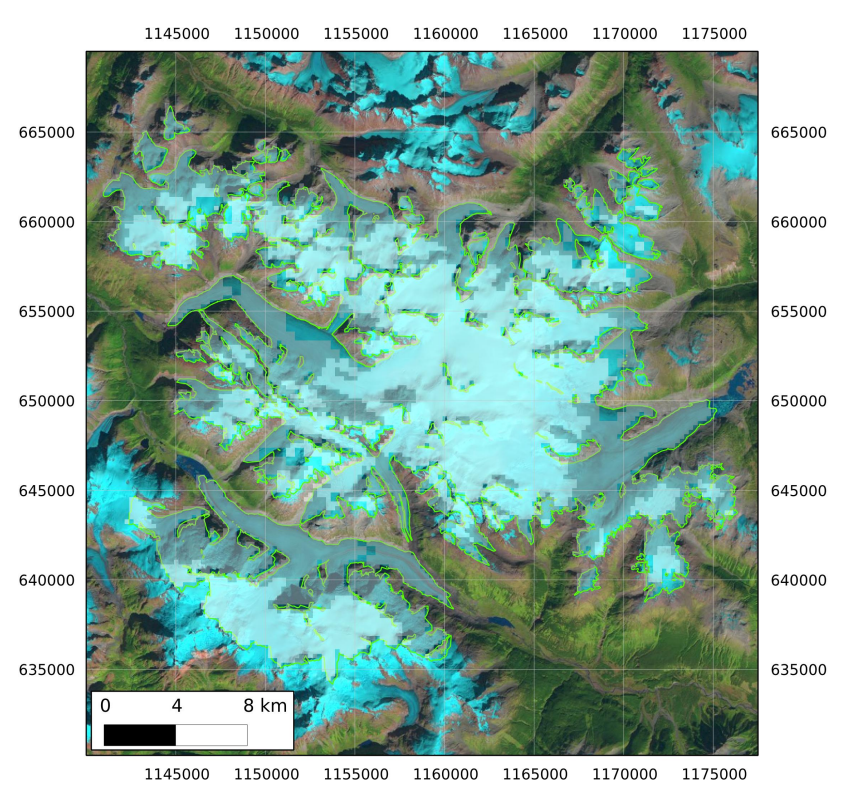

(b) Automated MOD02QKM classification

Fig. 8. Landsat 5 scene of the Lillooet Icefield and Bridge Glacier, 4 October, with (a) manual classification, and (b) MOD02QKM automated classification of snow (white) and ice (grey).

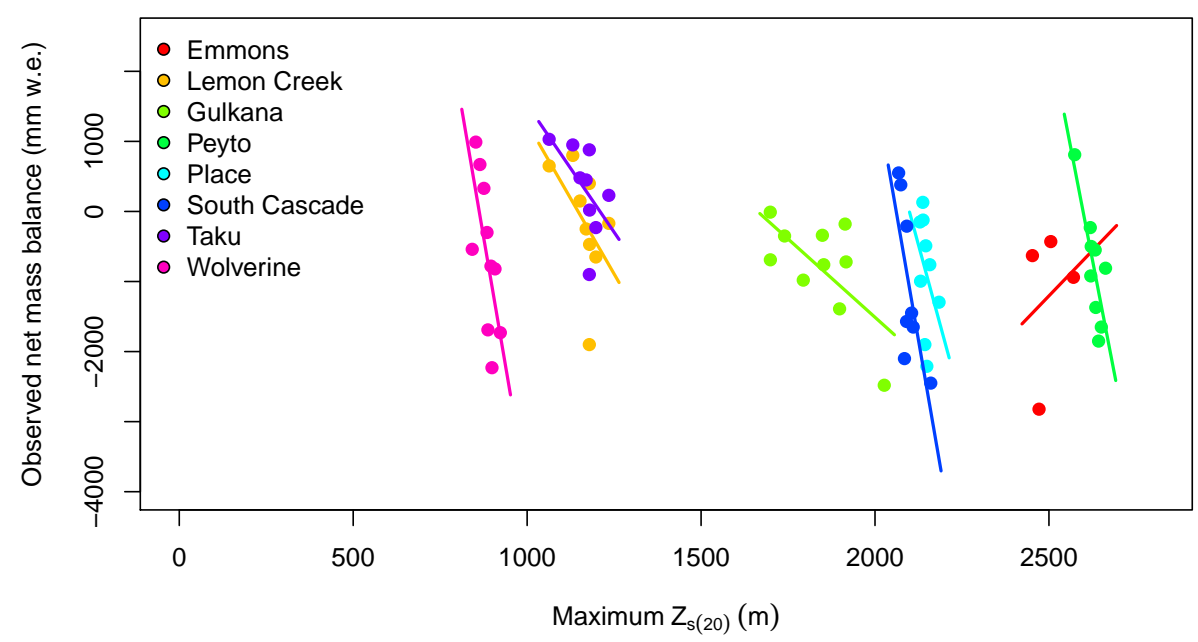

Fig. 9. ELA est versus observed net mass balance at eight index glacier sites, 2000-2009.

MOD02QKM imagery illustrate the skill of the cluster analysis method. While some classification errors exist on shaded slopes, the derived snow line metrics are similar. Future research should examine the glacier facies detection method presented here with the MODSCAG approach (e.g. Rittger et al., 2013).

Significant positive trends in the $Z_{S(20)}$ regional ELA proxy were identified at two continental sites (Peyto and Gulkana glaciers) over the period 2000-2011. No significant trends were identified at the other sites, though this does not imply that glacier mass balance was neutral or positive. Indeed, net glacier mass balance at the study sites was nega- tive $74 \%$ of the time during this period. Persistent negative glacier mass balance indicates that the annual ELA is higher than that required for a neutral mass balance $\left(E L A_{b n=0}\right)$. The absence of a trend in ELA combined with observations of negative mass balance would suggest that the current mean ELA is greater than $E A_{b n=0}$.

Geodetically determined rates of glacier mass change found in this study corroborate the continued loss of glacier mass in western North America observed from surface mass balance records (Zemp et al., 2011). Our estimates of mass loss are comparable with those found in other regions, though slightly lower. A geodetic balance of $-1.26 \mathrm{mw}$.e. $\mathrm{a}^{-1}$ 
Table 6. Regional ELA anomaly correlation matrix. Correlations significant at $p=0.1\left(^{*}\right)$ and $p=0.05\left({ }^{* *}\right)$ are noted.

\begin{tabular}{lllllllllll}
\hline & Columbia & Emmons & Gulkana & Juneau & Lillooet & Peyto & Place & Sittakanay & S. Cascade & Wolverine \\
\hline Columbia & 1.00 & $0.62^{* *}$ & 0.24 & $0.51^{*}$ & $0.52^{*}$ & $0.75^{* *}$ & 0.02 & 0.16 & 0.46 & 0.11 \\
Emmons & $0.62^{* *}$ & 1.00 & -0.32 & -0.01 & $0.59^{* *}$ & 0.27 & 0.39 & -0.25 & $0.61^{* *}$ & -0.22 \\
Gulkana & 0.24 & -0.32 & 1.00 & 0.35 & 0.26 & 0.41 & -0.22 & 0.20 & 0.08 & 0.23 \\
Juneau & $0.51^{*}$ & -0.01 & 0.35 & 1.00 & 0.37 & $0.82^{* *}$ & 0.09 & $0.73^{* *}$ & 0.24 & 0.45 \\
Lillooet & $0.52^{*}$ & $0.59^{* *}$ & 0.26 & 0.37 & 1.00 & 0.48 & 0.48 & 0.24 & $0.72^{* *}$ & -0.17 \\
Peyto & $0.75^{* *}$ & 0.27 & 0.41 & $0.82^{* *}$ & 0.48 & 1.00 & 0.21 & 0.49 & $0.50^{*}$ & 0.17 \\
Place & 0.02 & 0.39 & -0.22 & 0.09 & 0.48 & 0.21 & 1.00 & 0.15 & $0.84^{* *}$ & 0.06 \\
Sittakanay & 0.16 & -0.25 & 0.20 & $0.73^{* *}$ & 0.24 & 0.49 & 0.15 & 1.00 & 0.06 & 0.27 \\
S. Cascade & 0.46 & $0.61^{* *}$ & 0.08 & 0.24 & $0.72^{* *}$ & $0.50^{*}$ & $0.84^{* *}$ & 0.06 & 1.00 & 0.02 \\
Wolverine & 0.11 & -0.22 & 0.23 & 0.45 & -0.17 & 0.17 & 0.06 & 0.27 & 0.02 & 1.00 \\
\hline
\end{tabular}

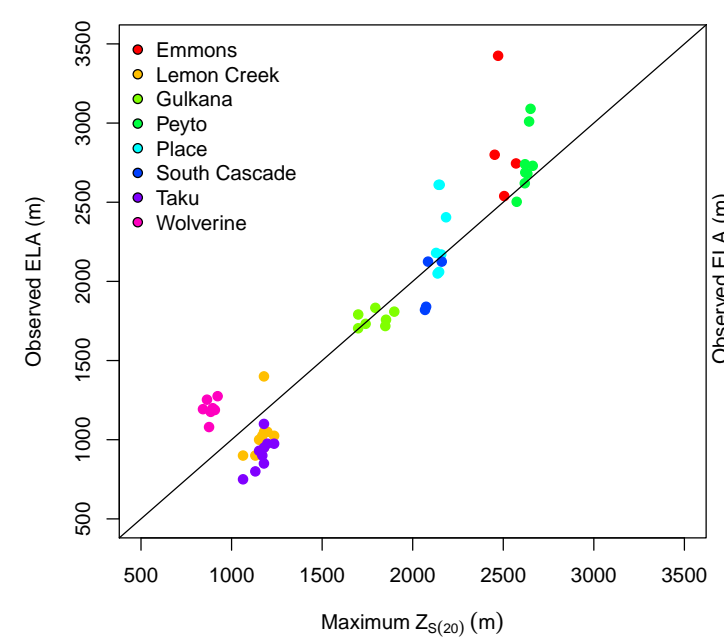

(a) ELA versus $Z_{S(20)}$

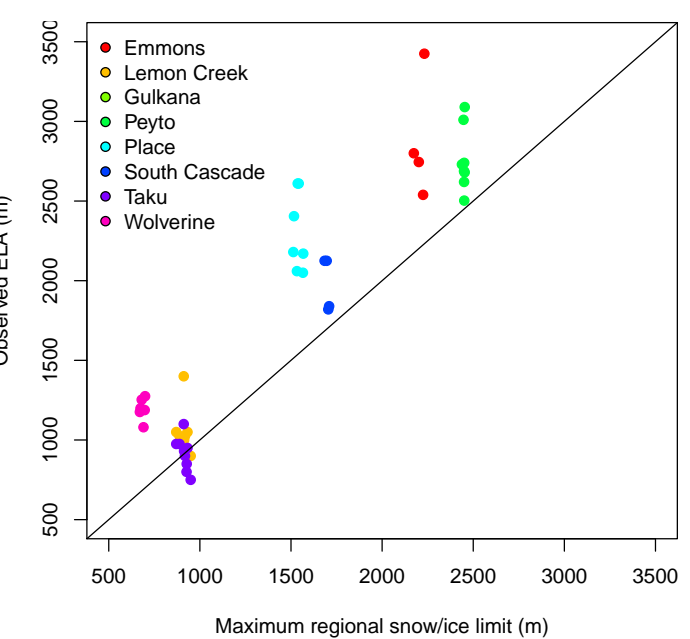

(b) ELA versus $Z_{\mathrm{SL}}$

Fig. 10. Index glacier ELAs observed from field data versus (a) maximum regional $Z_{S(20)}$ and (b) maximum regional $Z_{\mathrm{SL}}, 2000-2009$.

Table 7. Geodetic and ELA est estimates of glacier mass change (in Gt), for Columbia, Lillooet, and Sittakanay icefields.

\begin{tabular}{lcccc}
\hline Site & Area $\left(\mathrm{km}^{2}\right)$ & Period & Geodetic $^{\mathrm{a}}$ & ELA \\
\hline Columbia & 216 & $2000-2009$ & $-0.62 \pm 0.11$ & $-0.74 \pm 0.67$ \\
Lillooet & 490 & $2000-2009$ & $-1.28 \pm 0.26$ & $-2.24 \pm 0.80$ \\
Sittakanay & 416 & $2000-2007^{\mathrm{b}}$ & $-2.10 \pm 0.57$ & $-3.00 \pm 0.59$ \\
\hline
\end{tabular}

a Error term derived by propagation of errors (Tennant et al., 2012).

${ }^{\mathrm{b}}$ Geodetic balance calculated from February 2000 to 2 July 2008.

was recently found for a site in northern Norway (Andreassen et al., 2012), while an overall geodetic balance of $-1.0 \mathrm{~m}$ w.e. $\mathrm{a}^{-1}$ was estimated for the Patagonian Icefield (Rignot et al., 2003). At South Cascade Glacier, Krimmel (1999) found geodetic balances ranging from -1.90 to $-0.24 \mathrm{~m}$ w.e. $\mathrm{a}-1$ between 1985 and 1997.

ELA $_{\text {est }}$-based estimates of glacier mass change are within the margins of error of the geodetic approach at all three sites studied, but only one estimate (Columbia Icefield) is within $20 \%$ of the geodetic approach. In all three cases, the
ELA $_{\text {est }}$ approach yields estimates of mass change that were more negative than the geodetic approach. Discrepancies between the approaches could arise from (1) improperly specified mass balance gradients, (2) errors in the regional ELA proxies, (3) differences in the dates of geodetic image acquisition and our calculation of end-of-season glacier mass change, and (4) unidentified errors in the geodetic balance calculations. We discuss these in sequence below.

At long-term mass balance sites where gradients can be estimated with a linear piecewise approach (Peyto and Place), we note no temporal trends in the fitted gradients above or below the ELA (Fig. 12). It is also possible that short-term mass balance records, or those that do not correspond with the dates of ELA observation (e.g. at Bridge and Andrei glaciers) are unsuitable for estimation of glacier mass change in a different period. Additionally, the extrapolation of mass balance gradients below the elevation range of the observations may introduce additional errors (e.g. at Sittakanay Icefield, Fig. 5). Following the work of Kuhn et al. (2009), we attempted to adjust the balance profiles using the differences 

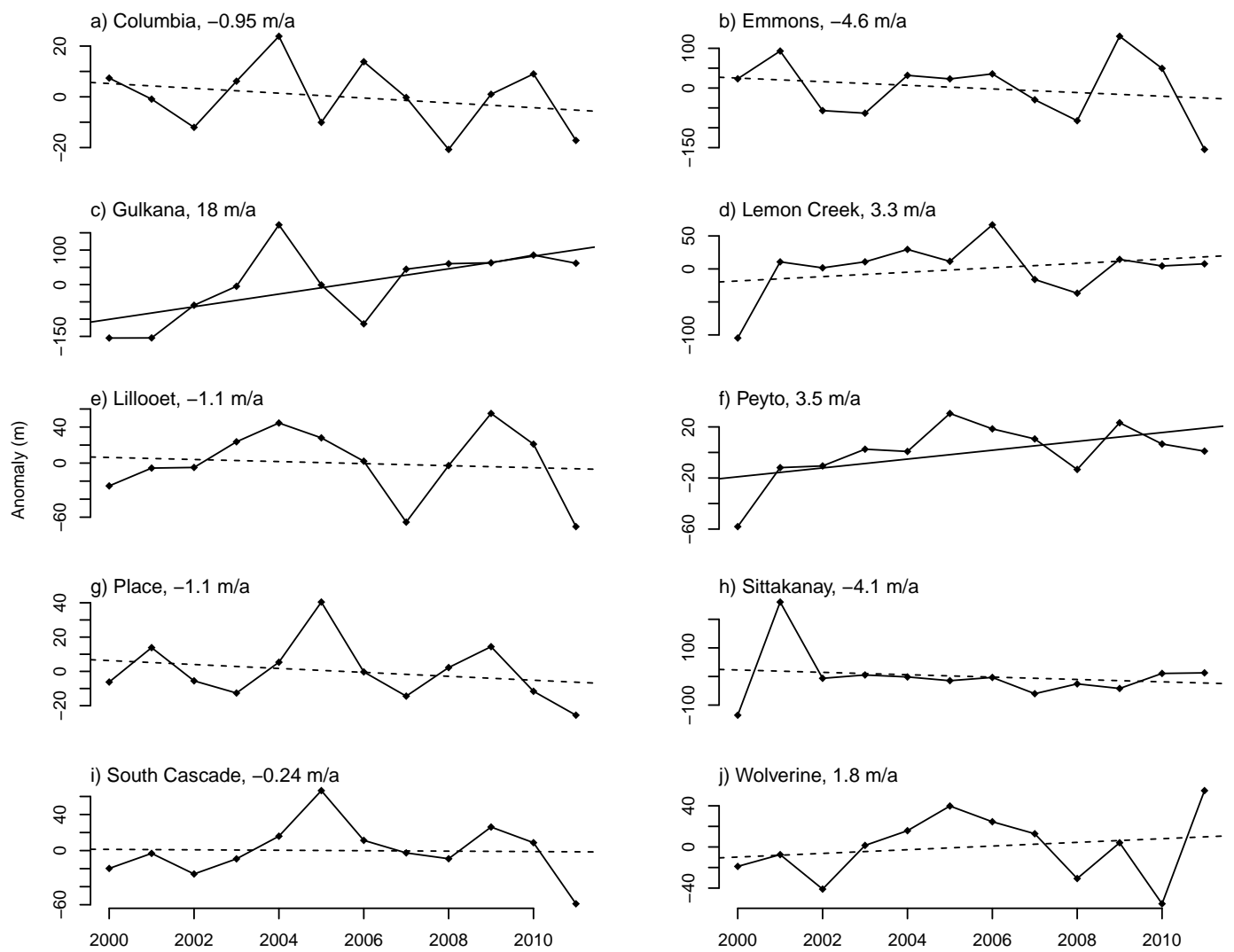

Fig. 11. Time series of regional ELA anomalies derived from MOD02QKM imagery. Least-squares regression fits are shown as dashed lines, trend magnitude (in $\mathrm{m} \mathrm{a}^{-1}$ ) is given in the figure caption, and solid trend lines are significant at $p=0.1$.

between the median elevation of the reference glaciers and the regional icefields (Table 3). In all cases this resulted in more negative estimates of glacier mass change.

The sensitivity of estimated glacier change based on ELA $_{\text {est }}$ was assessed by recalculating glacier mass change using different balance gradients at the Lillooet Icefield. The original estimate $(-2.24 \mathrm{Gt})$ uses mass balance gradients from Bridge Glacier (1977-1985). If we use all available mass balance gradient data from Place Glacier (19662005), located $75 \mathrm{~km}$ southeast of the Lillooet Icefield, the mass loss estimate nearly doubles to $-4.14 \mathrm{Gt}$. The use of mass balance gradients derived from data at Andrei Glacier and Peyto Glacier results in mass change estimates of -2.25 and $-2.83 \mathrm{Gt}$, respectively. Applying 2000-2007 averaged mass balance gradients obtained from regionally downscaled climate data (F. Anslow, unpublished data) also results in a similar mass change of $-2.38 \mathrm{Gt}$.

Errors in the ELA proxy may provide another explanation for the discrepancy between geodetic and ELA $A_{\text {est }}$ modelled mass change. Values of MODIS-derived ELA proxies will be sensitive to the availability of cloud-free imagery, though the use of lowess smoothers provides a conservative estimate of the maximum value of $Z_{S(20)}$. However, while this ELA metric will not necessarily correspond with the ELA observed at the index glacier due to the regional variability of snow line elevation, the observed trends should be approximately the same.

There may be a small source of error introduced by differences in the dates of geodetic image acquisition and our assumed end of ablation season calculations of mass change. SRTM data were collected in February 2000, and our assumption that this represents the end-of-summer surface elevation in 1999 may introduce a seasonal snow accumulation signal. We further assume that SPOT data collected in late July 2009 (Columbia, Lillooet) represents the surface elevation at the end of 2009, while SPOT data collected in early July 2008 (Sittakanay) represents the surface elevation at the end of 2007. Significant amounts of glacier ice melt will occur in July when glacier ice is exposed and solar radiation and air temperatures remain high.

Finally, it is possible that unidentified sources of error exist in the geodetic calculations. We were unable to calculate a correction for SRTM radar penetration for the Lillooet Icefield, which showed the greatest difference between geodetic and modelled glacier mass change. Further unidentified errors in our geodetic calculations may be a contributing factor in the differences between modelled and geodetic estimates of glacier mass change. 

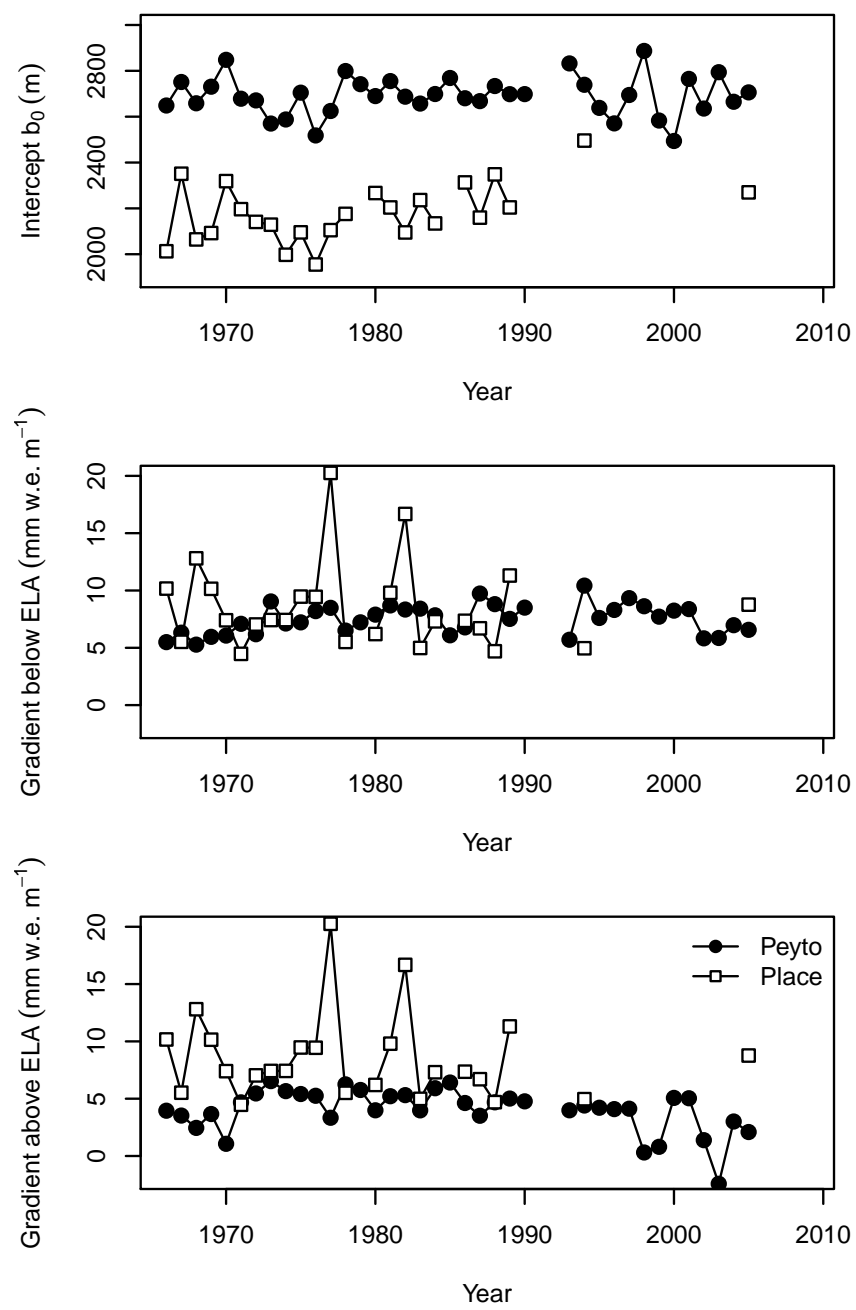

Fig. 12. Time series of fitted mass balance coefficients for Peyto and Place glaciers.

Our results further demonstrate the need to compare modelled estimates of glacier mass change with geodetic approaches. The use of MODIS-derived ELA est $_{\text {and mass bal- }}$ ance gradients demonstrated here is limited by the need for appropriate mass balance gradients, by the size of the glacierized area being analysed, and by the availability of cloudfree scenes. The approach developed in this study is furthermore not applicable for tidewater glaciers or debris-covered glaciers, but it could be employed in other regions where observations or modelled estimates of glacier mass balance gradients are available (e.g. the Andes or the Himalayas). We also recommend further comparisons between the ELA $\mathrm{est}_{\mathrm{est}}$ method developed here and the MODIS-retrieved albedo approach (Dumont et al., 2012). Where suitable test data exist, future research should also determine if cluster analysis methods are sufficient for extracting three glacier surface classes (snow, firn, and ice). Finally, glacier facies maps developed in this study can be used to calibrate and test dis- tributed glacier mass balance and hydrologic models at daily timesteps.

\section{Conclusions}

Cluster analyses of MOD02QKM visible and near-infrared imagery were used to generate daily ablation season snow and ice coverages over large glaciers and icefields, with marked improvements over the MOD10 snow product. Significant relations exist between ground-based mass balance observations and regional MODIS-derived ELA proxies, and significant positive trends in the $Z_{S(20)}$ metric are observed at two continental locations. When applied to individual icefields, estimates of total mass change generated from regional ELA proxies are more negative than traditional geodetic approaches, which suggests that further improvements to the ELA $_{\text {est }}$ modelling approach are required. Our geodetic results are consistent with the rates of mass change observed in previous studies, and we find continued overall net mass loss at three large icefields in western North America. The cluster analysis technique developed in this study will be useful for hydrological and glacier mass balance model calibration. Alternative approaches for the estimation of regional glacier mass change are critical, as large mountain glaciers and icefields are expected to be one of the largest contributors to sea level rise over the next century.

Acknowledgements. This work was supported by BC Hydro, the Western Canadian Cryospheric Network (WC2N) and the Canadian Foundation for Climate and Atmospheric Science (CFCAS), and NSERC Discovery Grants to BM and RDM. We thank F. Anslow for the modelled mass balance fields, M. Zemp for supplying the glacier mass balance data, F. Weber of BC Hydro for supplying the internal mass balance reports, and acknowledge the commitment and efforts of agencies and investigators who provide mass balance data to the WGMS: W. R. Bidlake (South Cascade), M. Demuth (Peyto and Place), R. March and S. O'Neel (Gulkana and Wolverine), M. Pelto (Lemon Creek and Taku), and J. Riedel (Emmons). M. Pelto, M. Zemp, and two anonymous reviewers provided valuable comments on the initial manuscript.

Edited by: A. Nolin

\section{References}

Andreassen, L. M., Kjøllmoen, B., Rasmussen, A., Melvold, K., and Nordli, Ø.: Langfjordjøkelen, a rapidly shrinking glacier in northern Norway, J. Glaciol., 58, 581-593, doi:10.3189/2012JoG11J014, 2012.

Arendt, A. A., Luthcke, S. B., and Hock, R.: Glacier changes in Alaska: can mass-balance models explain GRACE mascon trends?, Ann. Glaciol., 50, 148-154, doi:10.3189/172756409787769753, 2009.

Armstrong, R., Raup, B., Khalsa, S., Barry, R., Kargel, J., Helm, C., and Kieffer, H.: GLIMS glacier database, Digital Media, avail- 
able at: http://www.glims.org, National Snow and Ice Data Center, Boulder, Colorado, USA, 2012.

Berthier, E., Schiefer, E., Clarke, G. K. C., Menounos, B., and Rémy, F.: Contribution of Alaskan glaciers to sea-level rise derived from satellite imagery, Nat. Geosci., 3, 92-95, doi:10.1038/ngeo737, 2010.

Bitz, C. M. and Battisti, D. S.: Interannual to decadal variability in climate and the glacier mass balance in Washington, western Canada, and Alaska, J. Climate, 12, 3181-3196, 1999.

Bolch, T., Menounos, B., and Wheate, R.: Landsat-based inventory of glaciers in western Canada, 1985-2005, Remote Sens. Environ., 114, 127-137, 2010.

Cazenave, A. and Nerem, R. S.: Present-day sea level change: Observations and causes, Rev. Geophys., 42, RG3001, doi:10.1029/2003RG000139, 2004.

Chinn, T. J., Heydenrych, C., and Salinger, M. J.: Use of the ELA as a practical method of monitoring glacier response to climate in New Zealand's Southern Alps, J. Glaciol., 51, 85-95, doi:10.3189/172756505781829593, 2005.

Demuth, M. and Keller, R.: Peyto Glacier: One Century of Science, chap. An assessment of the mass balance of Peyto Glacier (1966$1995)$ and its relation to recent and past-century climatic variability, 83-132, Environment Canada. National Hydrology Research Institute, Saskatoon, Saskatchewan., 1997.

Déry, S. J. and Brown, R. D.: Recent Northern Hemisphere snow cover extent trends and implications for the snow-albedo feedback, Geophys. Res. Lett., 34, L22504, doi:10.1029/2007GL031474, 2007.

Dumont, M., Gardelle, J., Sirguey, P., Guillot, A., Six, D., Rabatel, A., and Arnaud, Y.: Linking glacier annual mass balance and glacier albedo retrieved from MODIS data, The Cryosphere, 6, 1527-1539, doi:10.5194/tc-6-1527-2012, 2012.

Dyurgerov, M.: Glacier mass balance and regime: data of measurements and analysis. Institute of Arctic and Alpine Research, Occasional Paper 55, University of Colorado, 2002.

Farr, T. G., Rosen, P. A., Caro, E., Crippen, R., Duren, R., Hensley, S., Kobrick, M., Paller, M., Rodriguez, E., Roth, L., Seal, D., Shaffer, S., Shimada, J., Umland, J., Werner, M., Oskin, M., Burbank, D., and Alsdorf, D.: The Shuttle Radar Topography Mission, Rev. Geophys., 45, RG2004, doi:10.1029/2005RG000183, 2007.

Fountain, A. G. and Vecchia, A.: How many stakes are required to measure the mass balance of a glacier?, Geogr. Ann. A, 81A, 563-573, 1999.

Gardelle, J., Berthier, E., and Arnaud, Y.: Slight mass gain of Karakoram glaciers in the early twenty-first century, Nat. Geosci., 5, 322-325, doi:10.1038/ngeo1450, 2012.

Gesch, D., Oimoen, M., Greenlee, S., Nelson, C., Steuck, M., and Tyler, D.: The National Elevation Dataset, Photogramm. Eng. Rem. S., 68, 5-11, 2002.

Hall, D. K. and Riggs, G. A.: Accuracy assessment of the MODIS snow products, Hydrol. Process., 21, 1534-1547, doi:10.1002/hyp.6715, 2007.

Hall, D., Riggs, G., Salomonson, V., DiGirolamo, N., and Bayr, K.: MODIS snow-cover products, Remote Sens. Environ., 83, 181194, 2002

Hall, D., Riggs, G., and Salomonson, V.: MODIS/Terra Snow Cover 5-min L2 Swath 500m V005, 2000-2009, Digital Media, National Snow and Ice Data Center, Boulder, CO., 2012.
Jacob, T., Wahr, J., Pfeffer, W., and Swenson, S.: Recent contributions of glaciers and ice caps to sea level rise, Nature, 482, 514-518, doi:10.1038/nature10847, 2012.

Jiskoot, H., Curran, C. J., Tessler, D. L., and Shenton, L. R.: Changes in Clemenceau Icefield and Chaba Group glaciers, Canada, related to hypsometry, tributary detachment, lengthslope and area-aspect relations, Ann. Glaciol., 50, 133-143, doi:10.3189/172756410790595796, 2010.

Klein, A. and Isacks, B.: Spectral mixture analysis of Landsat thematic mapper images applied to the detection of the transient snowline on tropical Andean glaciers, Global Planet. Change, 22, 139-154, 1999.

Krimmel, R.: Analysis of difference between direct and geodetic mass balance measurements at South Cascade Glacier, Washington, Geogr. Ann. A, 653-658, 1999.

Kuhn, M., Abermann, J., Bacher, M., and Olefs, M.: The transfer of mass-balance profiles to unmeasured glaciers, Ann. Glaciol., 50, 185-190, doi:10.3189/172756409787769618, 2009.

Larsen, C. F., Motyka, R. J., Arendt, A. A., Echelmeyer, K. A., and Geissler, P. E.: Glacier changes in southeast Alaska and northwest British Columbia and contribution to sea level rise, J. Geophys. Res.-Earth, 112, F01007, doi:10.1029/2006JF000586, 2007.

Lopez, P., Sirguey, P., Arnaud, Y., Pouyaud, B., and Chevallier, P.: Snow cover monitoring in the Northern Patagonia Icefield using MODIS satellite images (2000 2006), Global Planet. Change, 61, 103-116, doi:10.1016/j.gloplacha.2007.07.005, 2008.

Luckman, B.: The Little Ice Age in the Canadian Rockies, Geomorphology, 32, 357-384, doi:10.1016/S0169-555X(99)00104$\mathrm{X}, 2000$.

Machguth, H., Paul, F., Kotlarski, S., and Hoelzle, M.: Calculating distributed glacier mass balance for the Swiss Alps from regional climate model output: A methodical description and interpretation of the results, J. Geophys. Res.-Atmos., 114, D19106, doi:10.1029/2009JD011775, 2009.

McCabe, G. J., Fountain, A. G., and Dyurgerov, M.: Variability in winter mass balance of Northern Hemisphere glaciers and relations with atmospheric circulation, Arct. Antarct. Alp. Res., 32, 64-72, 2000.

Mokievsky-Zubok, O.: Glaciological studies in Iskut River Basin, 1989, Internal Report, B.C. Hydro, 1990.

Mokievsky-Zubok, O.: Glaciological studies in Iskut River Basin, 1990, Internal Report, B.C. Hydro, 1991.

Mokievsky-Zubok, O.: Glaciological studies in Iskut River Basin, 1991, Internal Report, B.C. Hydro, 1992.

Mokievsky-Zubok, O., Ommanney, O. S. J., and Power, J.: NHRI Glacier Mass Balance 1964-1984 (Cordillera and Arctic), National Hydrology Research Institute, Environment Canada, 59 pp., 1985.

Moore, R. D. and Demuth, M. N.: Mass balance and streamflow variability at Place Glacier, Canada, in relation to recent climate fluctuations, Hydrol. Process., 15, 3473-3486, doi:10.1002/hyp.1030, 2001.

Moore, R. D., Fleming, S. W., Menounos, B., Wheate, R., Fountain, A., Stahl, K., Holm, K., and Jakob, M.: Glacier change in western North America: influences on hydrology, geomorphic hazards and water quality, Hydrol. Process., 23, 42-61, doi:10.1002/hyp.7162, 2009. 
NASA: MODIS/Terra Calibrated Radiances 5-Min L1B Swath 250 m, 2000-2009, Digital Media, Level 1 and Atmsophere Archive and Distribution System, http://ladsweb.nascom.nasa. gov/, 2012.

Nuth, C. and Kääb, A.: Co-registration and bias corrections of satellite elevation data sets for quantifying glacier thickness change, The Cryosphere, 5, 271-290, doi:10.5194/tc-5-271-2011, 2011.

Østrem, G.: The transient snowline and glacier mass balance in southern British Columbia and Alberta, Canada, Geogr. Ann. A, 55, 93-106, 1973.

Østrem, G.: ERTS data in glaciology - an effort to monitor glacier mass balance from satellite imagery, J. Glaciol., 15, 403-416, 1975.

Parajka, J. and Blöschl, G.: The value of MODIS snow cover data in validating and calibrating conceptual hydrologic models, J. Hydrol., 358, 240-258, 2008.

Pelto, M.: Utility of late summer transient snowline migration rate on Taku Glacier, Alaska, The Cryosphere, 5, 1127-1133, doi:10.5194/tc-5-1127-2011, 2011.

Pelto, M. S. and Riedel, J.: Spatial and temporal variations in annual balance of North Cascade glaciers, Washington 1984-2000, Hydrol. Process., 15, 3461-3472, 2001.

Rabatel, A., Dedieu, J.-P., and Vincent, C.: Using remote-sensing data to determine equilibrium-line altitude and mass-balance time series: validation on three French glaciers, 1994-2002, J. Glaciol., 51, 539-546, doi:10.3189/172756505781829106, 2005.

Radić, V. and Hock, R.: Regional and global volumes of glaciers derived from statistical upscaling of glacier inventory data, J. Geophys. Res.-Earth, 115, F01010, doi:10.1029/2009JF001373, 2010.

Radić, V. and Hock, R.: Regionally differentiated contribution of mountain glaciers and ice caps to future sea-level rise, Nat. Geosci., 4, 91-94, doi:10.1038/ngeo1052, 2011.

Raper, S. C. B. and Braithwaite, R. J.: Low sea level rise projections from mountain glaciers and icecaps under global warming, Nature, 439, 311-313, doi:10.1038/nature04448, 2006.
Rignot, E., Rivera, A., and Casassa, G.: Contribution of the Patagonia Icefields of South America to sea level rise, Science, 302, 434-437, 2003.

Rittger, K., Painter, T. H., and Dozier, J.: Assessment of methods for mapping snow cover from MODIS, Adv. Water Resour., 51, 367-380, doi:10.1016/j.advwatres.2012.03.002, 2013.

Schiefer, E., Menounos, B., and Wheate, R.: Recent volume loss of British Columbian Glaciers, Canada, Geophys. Res. Lett., 34, L16503, doi:10.1029/2007GL030780, 2007.

Sirguey, P., Mathieu, R., and Arnaud, Y.: Subpixel monitoring of the seasonal snow cover with MODIS at $250 \mathrm{~m}$ spatial resolution in the Southern Alps of New Zealand: Methodology and accuracy assessment, Remote Sens. Environ., 113, 160-181, 2009.

Stahl, K. and Moore, R. D.: Influence of watershed glacier coverage on summer streamflow in British Columbia, Canada, Water Resour. Res., 42, W06201, doi:10.1029/2006WR005022, 2006.

Tennant, C., Menounos, B., Ainslie, B., Shea, J., and Jackson, P.: Comparison of modeled and geodetically-derived glacier mass balance for Tiedemann and Klinaklini glaciers, southern Coast Mountains, British Columbia, Canada, Global Planet. Change, 82, 74-85, doi:10.1016/j.gloplacha.2011.11.004, 2012.

Williams, R., Hall, D., and Benson, C.: Analysis of glacier facies using satellite techniques, J. Glaciol., 37, 120-128, 1991.

Winther, J., Gerland, S., Ørbæk, J., Ivanov, B., Blanco, A., and Boike, J.: Spectral reflectance of melting snow in a High Arctic watershed on Svalbard: some implications for optical satellite remote sensing studies, Hydrol. Process., 13, 2033-2049, 1999.

Zemp, M., Nussbaumer, S., Gärtner-Roer, I., Hoelzle, M., Paul, F., and Haeberli, W. (Eds.): Glacier Mass Balance Bulletin No. 11 (2008-2009), ICSU (WDS)/IUGG (IACS)/UNEP/UNESCO/WMO, World Glacier Monitoring Service, Zurich, Switzerland, 2011. 